\title{
ARTICLE \\ Impact of increasing water temperature on growth, photosynthetic efficiency, nutrient consumption, and potential toxicity of Amphidinium cf. carterae and Coolia monotis (Dinoflagellata)
}

Impacto del aumento de temperatura sobre el crecimiento, actividad fotosintética, consumo de nutrientes y toxicidad potencial de Amphidinium cf. carterae y Coolia monotis (Dinoflagellata)

\author{
Aldo Aquino-Cruz ${ }^{1}$ and Yuri B. Okolodkov ${ }^{2}$ \\ ${ }^{1}$ University of Southampton, National Oceanography Centre Southampton, European Way, Waterfront Campus, SO14 3HZ, Southampton, \\ Hampshire, England, UK. aldoaqcz@yahoo.com \\ ${ }^{2}$ Laboratorio de Botánica Marina y Planctología, Instituto de Ciencias Marinas y Pesquerías, Universidad Veracruzana, Calle Hidalgo \\ 617, Col. Río Jamapa, Boca del Río, 94290, Veracruz, México. yuriokolodkov@ yahoo.com
}

\begin{abstract}
Resumen.- A nivel mundial, el aumento de la temperatura en ecosistemas marinos podría beneficiar la formación de florecimientos algales nocivos. Sin embargo, la comprensión de la influencia del aumento de la temperatura sobre el crecimiento de poblaciones nocivas de dinoflagelados bentónicos es prácticamente inexistente. Se investigó el impacto del aumento de la temperatura entre 5 y $30^{\circ} \mathrm{C}$ en dos cepas de dinoflagelados bentónicos aislados del Fleet Lagoon, Dorset, sur de Inglaterra, y su toxicidad potencial fue determinada a través de dos tipos de bioensayos (mortalidad del copépodo Tigriopus californicus y actividad hemolítica en eritrocitos de pollo). Las cepas crecieron en monocultivos en medio $\mathrm{f} / 2$ (agua de mar enriquecida), suministradas con irradiancias de 35 a $70 \mu \mathrm{mol} \mathrm{m} \mathrm{m}^{-2} \mathrm{~s}^{-1}$ bajo un fotoperiodo de $12: 12 \mathrm{~h}$ (luz/oscuridad). La abundancia, la eficiencia fotoquímica máxima del fotosistema PSII ( $\mathrm{Fv} / \mathrm{Fm})$, el consumo de nutrientes $\left(\mathrm{N}-\mathrm{NO}_{3}+\mathrm{N}-\mathrm{NO}_{2}\right.$ y $\left.\mathrm{P}-\mathrm{PO}_{4}\right)$ y las tasas de crecimiento se determinaron a temperaturas entre 5 y $30^{\circ} \mathrm{C}$ en monocultivos de Amphidinium cf. carterae y Coolia monotis. El aumento de temperatura causó tasas de crecimiento mayores en las dos cepas examinadas. Temperaturas elevadas $\left(25-30^{\circ} \mathrm{C}\right)$ se asociaron con el óptimo crecimiento de A. cf. carterae, mientras que la máxima tasa de crecimiento en $\mathrm{C}$. monotis se registró entre 15 y $25^{\circ} \mathrm{C}$. Las tasas de crecimiento de $\mathrm{A}$. cf. carterae fueron significativamente mayores a las registradas en C. monotis. El declive de Fv/Fm se asoció con condiciones deficientes de crecimiento para ambas especies. La máxima Fv/Fm no se registró asociada a la temperatura de óptimo crecimiento en ambas especies. La mortalidad del copépodo y el efecto lítico en eritrocitos confirmaron la producción potencial de compuestos nocivos en ambas especies de dinoflagelados.
\end{abstract}

Palabras clave: Amphidinium carterae, Coolia monotis, tasa de crecimiento, temperatura, toxicidad

\begin{abstract}
The effect of global warming on marine ecosystems may benefit the formation of harmful algal blooms. However, our understanding of the effect of higher water temperatures on the growth of harmful benthic dinoflagellates in the environment is practically unknown. The effect of increasing water temperatures from 5 to $30^{\circ} \mathrm{C}$ on the growth of two strains of benthic dinoflagellates (Amphidinium cf. carterae and Coolia monotis) isolated from the Fleet Lagoon, Dorset, south of England, was investigated, and their potential toxicity was assessed using two types of bioassays (mortality of the copepod Tigriopus californicus and haemolytic activity of chicken red blood cells). Benthic dinoflagellate strains were grown in $\mathrm{f} / 2$ medium at irradiances of $35-$ $70 \mu \mathrm{mol} \mathrm{m} \mathrm{m}^{-2} \mathrm{~s}^{-1}$ and under a $12 \mathrm{~h} \mathrm{L:12h} \mathrm{D}$ photoperiod. Cell abundance, maximum quantum yield of photosystem II (Fv/Fm), nutrient consumption $\left(\mathrm{N}-\mathrm{NO}_{3}+\mathrm{N}-\mathrm{NO}_{2}\right.$ and $\left.\mathrm{P}-\mathrm{PO}_{4}\right)$, and growth rates were determined in dinoflagellate cultures at growth temperatures between 5 and $30^{\circ} \mathrm{C}$. Increasing water temperatures caused increased growth rates of the species. Elevated temperatures $\left(25-30^{\circ} \mathrm{C}\right)$ were linked to the optimum growth of A. cf. carterae, while maximal growth rates in C. monotis were recorded between 15 and $25^{\circ} \mathrm{C}$. A. cf. carterae had significantly higher growth rates than $\mathrm{C}$. monotis. Declining $\mathrm{Fv} / \mathrm{Fm}$ values indicated unsuitable growth conditions in culture for both species. The highest Fv/Fm values recorded had no relation to the optimum growth temperature for either species. Copepod mortality and lysis of erythrocytes confirmed that both dinoflagellate species may produce chemical compounds with potentially noxious effects.
\end{abstract}

Key words: Amphidinium carterae, Coolia monotis, growth rate, temperature, toxicity 


\section{INTRODUCTION}

More than 30 species of benthic dinoflagellates are toxinproducing microalgae (Hoppenrath et al. 2014) and may form harmful algal blooms (HABs) in tropical and temperate aquatic ecosystems worldwide (Nakajima 1981, Penna et al. 2005, Shears \& Ross 2009, GEOHAB 2012, Hoppenrath et al. 2014, Ismael 2014). These microorganisms live epiphytically on macroalgae and seagrasses in coral reef zones, interstitial spaces in marine sediments, and associated with substrata in mangroves (GEOHAB 2012, Hoppenrath et al. 2014). In these benthic ecosystems, changes in water temperature determine seasonal trends and densities of microalgae communities (Raven \& Geider 1988, Edwards et al. 2006). Benthic HAB species have become of global concern because rapid environmental changes in shallow coastal waters (water warming, eutrophication) may increase the development of HAB events worldwide (Peperzak 2003, Beardall \& Stojkovic 2006, Edwards et al. 2006, Hallegraeff 2010, Bresnan et al. 2013). Despite the incipient knowledge of climate change (water warming) on HABs, diverse experimental predictions argue that higher water temperatures in aquatic environment may stimulate the optimum growth of HAB species (Peperzak 2003, Beardall \& Stojkovic 2006, Edwards et al. 2006, Hallegraeff 2010, Bresnan et al. 2013). Nonetheless, there is little understanding of the influence of warmer water temperatures on the growth and toxin production of benthic HAB species in the environment.

The genera Amphidinium Clap. et Lachm. emend. Flø Jørgensen, S. Murray et Daugbjerg, Prorocentrum Ehrenb., Gambierdiscus Adachi et Fukuyo, Fukuyoa F. Gómez, D. Qui, R.M. Lopez et S. Lin, Ostreopsis Schmidt, and Coolia Meunier are known to form non-pelagic blooms in both tropical and temperate coastal waters (Morton et al. 1992, Gómez et al. 2015), and some species are toxic to higher organisms, including humans (Hallegraeff 2003). Noxious events of Amphidinium cf. carterae Hulburt and Coolia monotis Meunier have been documented in coastal waters (Ismael et al. 1999, Armi et al. 2010, Ismael 2014), but their mechanism of toxicity in the environment remains to be revealed. $A$. cf. carterae is recognized as being a fast growing dinoflagellate $(\mu$ $=2.7$ day $^{-1}$, Ismael et al. 1999) compared to other benthic and planktonic microalgae (Gerath \& Chisholm, 1989, Strom \& Morello 1998, Lee et al. 2003). This species comprised 85\% of the total phytoplankton abundance in intertidal pools in the North Arabian Sea (Baig et al. 2006). More than 20 secondary metabolites have been identified, isolated, and characterized to molecular level from A. cf. carterae (Kobayashi \& Tsuda 2004). These compounds have demonstrated haemolytic (Nakajima et al. 1981, Nayak et al. 1997, Meng et al. 2010), cytotoxic (Ismael et al. 1999, Jeong et al. 2003), ichthyotoxic and antifungal activities (Echigoya et al. 2005) and are recognized as amphidinolides. To date, amphidinol-3 has been considered the most active secondary metabolite produced by $A$. cf. carterae, and it exhibits a potent haemolytic activity against human erythrocytes and an antifungal activity against the ascomycetous fungus Aspergillus niger van Tieghem (de Vicente et al. 2006).

Toxicological analyses of some strains of Coolia monotis have been linked to cytotoxic effects (Nakajima et al. 1981) and mortality of both Artemia and mice (Rhodes \& Thomas 1997, Rhodes et al. 2000, 2010). In the North Lake of Tunis, the growth of $C$. monotis cells produced a toxic bloom associated with the mortality of juvenile fish (Armi et al. 2010). Few reports have provided evidence of the chemical structure of toxins in $C$. monotis. The first toxin characterized from a strain of $C$. monotis was cooliatoxin (a potent cardiac stimulant, Holmes et al. 1995); some other secondary metabolites have also been reported, e.g., cooliatin, an unprecedented dioxocyclononane (Liang et al. 2009), and unknown analogues of a polyether compound (Rhodes et al. 2000).

The Fleet Lagoon is one of the largest tidal and valued lagoons in the UK (Weber et al. 2006). It is a shallow marine ecosystem (depth $<2 \mathrm{~m}$ ) that possesses a rich diversity of phytoplankton species (Nascimento 2003), including the harmful genera Amphidinium and Coolia. Harmful effects of these benthic genera in English waters have not yet been reported. In coastal waters of the UK, many uncertainties persist with regard to how water warming might accelerate the reproduction, bloom formation and toxin production by harmful dinoflagellates (Bresnan et al. 2013), such as A. cf. carterae and C. monotis. To broaden our understanding of how temperature modulates the dynamics of benthic dinoflagellate growth, this work aimed (1) to determine the effect of increasing sea water temperature on the growth and photosynthetic efficiency $(F v / F m)$ of $A$. cf. carterae and $C$. monotis, and (2) to assess the potential toxicity of the isolates based on mortality of harpacticoid copepods and lysis of red blood cells.

\section{MATERIAL AND METHODS}

\section{SAmpling and establishment of CUltures}

The epibenthic dinoflagellates Amphidinium cf. carterae and Coolia monotis were isolated from samples of the native macroalgae Chaetomorpha linum (O.F. Müll.) Kütz. and Ulva lactuca L., and from the seagrasses Ruppia maritima L., Zostera noltii Hornem. and Z. marina L. collected in May 2008 from shallow brackish waters of the Fleet Lagoon 
$\left(50^{\circ} 36^{\prime} 40^{\prime \prime} \mathrm{N}\right.$ and $\left.02^{\circ} 31^{\prime} 10^{\prime \prime} \mathrm{W}\right)$. Macrophytes and seagrasses were gently collected underwater by hand and placed into plastic bags with seawater (salinity 28-30). Sampling bags contained 1-3 species of the macroalgae listed above and were maintained in the dark, in a cold room $\left(5^{\circ} \mathrm{C}\right)$ for up to 3 days prior to microscopic analysis. Plastic bags were gently shaken for $30 \mathrm{~s}$ to detach dinoflagellates from macrophytes. Aliquots of $\sim 0.5 \mathrm{ml}$ (3-4 $\mathrm{ml}$ of water in total) were examined under a Nikon Eclipse E200 compound microscope, and single cells of $A$. cf. carterae and $C$. monotis were isolated using glass micropipettes. Microalgal monocultures were started in 96-well plates (Thermo Scientific Nunc, USA) filled with f/2 medium (Sigma G0154, Guillard \& Ryther 1962) prepared with filtered seawater $(0.2 \mu \mathrm{m})$ from the Fleet Lagoon (salinity 28 30). Growing cells in wells were later transferred to $250 \mathrm{ml}$ conical flasks filled with $\mathrm{f} / 2$ culture medium. Cultures of epibenthic dinoflagellates were initiated at growth temperatures of $18-20^{\circ} \mathrm{C}$, with a $12: 12 \mathrm{~h}$ light:dark photoperiod, under irradiances of $35-70 \mu \mathrm{mol}$ photons $\mathrm{m}^{-2} \mathrm{~s}^{-1}$. All monocultures were non-axenic.

\section{GrowTH EXPERIMENTS}

Growth experiments were carried out with single strains of $A$. cf. carterae and C. monotis. The species were grown in $1 \mathrm{~L}$ of f/2 media (Guillard \& Ryther 1962). The initial cell abundances were on the order of magnitude of $10^{3}$ and $10^{2}$ cells $\mathrm{mL}^{-1}$ in $A$. cf. carterae and $C$. monotis cultures, respectively. Each species was grown in triplicate cultures at water temperatures of 5, 10, 15,20 , and $25^{\circ} \mathrm{C}$; duplicates were used at $30^{\circ} \mathrm{C}$. Experiments were conducted in incubators (Mercia Scientific, Southam, Warwickshire, England, UK) under an irradiance range of 35$70 \mu \mathrm{mol}$ photons $\mathrm{m}^{-2} \mathrm{~s}^{-1}$. Highest irradiances were measured close to lamps (white light illumination). Dinoflagellate taxawere maintained in exponential growth $\left(18-20^{\circ} \mathrm{C}\right)$ for at least 4 weeks, and the acclimation time of taxa was two days at each growth temperature prior to growth experiments. Therefore, this study was constrained to short-term acclimation responses in A. cf. carterae and C. monotis within the range of growth temperatures, although some studies have proved that shortterm temperature acclimation of algae did not alter metabolic responses when rapid environmental changes occur (Michel et al. 1989, Ritter et al. 2014). A. cf. carterae and C. monotis cultures were sampled every 2 and 4 days for a period of 4 and 6 weeks, respectively. Growth experiments were performed at two periods: first, at temperatures between 5 and $15^{\circ} \mathrm{C}$ and later from 20 to $30^{\circ} \mathrm{C}$. Cell abundance and maximum quantum yield of photosystem II (PSII) $(F v / F m)$ charge separation were measured in algal cultures as described below.

\section{Cell abundance estimation}

Culture flasks were gently mixed before sampling under a laminar flow fume hood. Culture sub-samples $(10 \mathrm{ml})$ were collected in glass tubes and fixed with glutaraldehyde (1\% final concentration). Cell counting was performed using a Coulter Counter Multisizer III with a $70 \mu \mathrm{m}$ aperture tube. Cell abundances in each sub-sample were quantified in triplicate. To validate the quantification method, 10 sampling points over the growth curves were compared to direct cell counts using a 1-mL Sedgwick-Rafter chamber, and results showed $>95 \%$ accuracy. Growth rates were computed from the slope of a linear plot of Ln-transformed cell counts over the exponential growth phase.

\section{Maximum Quantum yield of PSII $\left(F_{V} / F_{M}\right)$}

The physiological state of cells (e.g., nutrient stress) in nonaerated cultures was determined by measuring the maximum quantum yield of PSII charge separation, which measures the probability that the energy of a photon absorbed will be used for photosynthesis, an indicator of photosynthetic efficiency ( $F v /$ Fm) (Moore et al. 2008, Suggett et al. 2009, From et al. 2014). Measurements were carried out by blue light flashes at $440 \mathrm{~nm}$ with a Fast Repetition Rate Fluorometer (FRRF, Chelsea Technologies Group Ltd, Surrey, UK) enabled for a saturation of PSII of 100 flashlets $1.1 \mu \mathrm{s}$ at $1.1 \mu \mathrm{s}$ time intervals. Values of $\mathrm{Fv} / \mathrm{Fm}$ were acquired using the manufacturer's software using the following equations:

$$
\begin{aligned}
& F v=F_{m}-F_{o} \\
& F v / F m=\frac{(F m-F o)}{F m}
\end{aligned}
$$

where $F v$ is the variable Chl- $a$ fluorescence; $F_{o}$ and $F_{m}$ are the minimum and maximum, respectively, in vivo Chl- $a$ fluorescence yield (relative) in a dark-adapted state. The reaction centers of PSII were relaxed in the dark for $25 \mathrm{~min}$ before a number of blue light flashes at $440 \mathrm{~nm}$ permitted the determination of $F_{o}$ and $F_{m}$ using a $4.5 \mathrm{ml}$ quartz cuvette. Six single FRRF measurements were performed per replicate, and $F v / F m$ values were averaged at each growth temperature using the FRRF software FastInP(Chelsea Technologies Group, Ltd, Molesey, Surrey, England, UK). $F_{v} / F_{m}$ in the cells was analyzed during the lag, exponential and stationary growth phases based on samples taken for cell counts.

\section{Nutrient Consumption $\left(\mathrm{N}-\mathrm{NO}_{3}+\mathrm{N}-\mathrm{NO}_{2}\right.$ and $\left.\mathrm{P}-\mathrm{PO}_{4}\right)$}

Nutrient analyses were conducted every 4-6 days. Thirty $\mathrm{ml}$ of culture were collected and filtered through $\mathrm{GF} / \mathrm{F}$ filters, and the filtrate was kept in plastic bottles at $-20^{\circ} \mathrm{C}$ before nutrient 
analysis. Samples were defrosted at room temperature and diluted $1 / 100$ using a solution of $\mathrm{NaCl}+$ MilliQ water (40\%). $\mathrm{N}-\mathrm{NO}_{3}+\mathrm{N}-\mathrm{NO}_{2}$ and $\mathrm{P}-\mathrm{PO}_{4}$ were determined in filtered water samples with a QuAAtro segmented flow autoanalyzer and standard colorimetric techniques (Grasshoff 1976, Kirkwood 1996). Each sample was analyzed in duplicate, and average values were used for each sampling point in replicate cultures. The detection limits of $\mathrm{N}-\mathrm{NO}_{3}+\mathrm{N}-\mathrm{NO}_{2}$ and $\mathrm{P}-\mathrm{PO}_{4}$ were 0.03 $\mu \mathrm{mol} \mathrm{L}{ }^{-1}$ and $0.01 \mu \mathrm{mol} \mathrm{L}^{-1}$, respectively. Nutrient analysis was carried out at the Biochemistry Laboratory at the National Oceanography Centre, Southampton, England, UK. Total nutrient $\left(\mathrm{N}-\mathrm{NO}_{3}+\mathrm{N}-\mathrm{NO}_{2}\right.$ and $\left.\mathrm{P}-\mathrm{PO}_{4}\right)$ removal from culture media was calculated as follow:

$$
\text { Nutrient consumption }\left(\mu \mathrm{mols} \mathrm{L}^{-1}\right)=\frac{C o-C i}{\mathrm{~N}}
$$

where $C o$ is nutrient concentration $\left(\mu\right.$ mols $\left.\mathrm{L}^{-1}\right)$ at an early exponential growth phase; $\mathrm{Ci}$ is the nutrient concentration at the end of the exponential growth; $\mathrm{N}$ was the change in cell concentration generated during the time (days) of $\mathrm{Co}$ and $\mathrm{Ci}$. Total nutrient consumption $\left(\mathrm{N}-\mathrm{NO}_{3}+\mathrm{N}-\mathrm{NO}_{2}\right.$ and $\mathrm{P}-\mathrm{PO}_{4} \mu$ mols cell $^{-1}$ ) over the exponential growth phase was then converted to $\mathrm{N}-\mathrm{NO}_{3}+\mathrm{N}-\mathrm{NO}_{2}$ and $\mathrm{P}-\mathrm{PO}_{4}$ picomols cell ${ }^{-1}$ day $^{-1}$.

\section{Haemolytic assay}

Chicken Erythrocyte Lysis Assay (ELA) was conducted to detect and quantify haemolytic compounds synthesized by $A$. cf. carterae and $C$. monotis. This study followed the method applied by Eschbach et al. (2001) and Neely \& Campbell (2006), although in our study we used chicken Red Blood Cells (RBCs) rather than fish RBCs. Chicken RBCs were provided by Seralab, UK, in $10 \%$ Alsevers solution, and they were used in bioassays within two weeks of delivery. Algal extracts were prepared with different cell abundances of $A$. cf. carterae $(0.01$, $0.05,0.25,0.5,1$, and $2 \times 10^{6}$ cells $\left.\mathrm{mL}^{-1}\right)$ and C. monotis $(0.2$, $0.5,1,2,3,4,5,10,20$, and $30 \times 10^{3}$ cells $\left.\mathrm{mL}^{-1}\right)$, and the percentage of haemolytic activity was estimated for the range of concentrations. Erythrocytes were incubated with the algal extracts in the dark at $20^{\circ} \mathrm{C}$ for $18 \mathrm{~h}$ prior to quantifying spectrophotometrically the lytic response of haemolytic compounds.

\section{Preparation of algal extracts}

Algal extracts were prepared from $A$. cf. carterae and $C$. monotis cells at the exponential growth phase only. These species were grown in cultures at $20^{\circ} \mathrm{C}$ using the growth conditions mentioned above. Cell pellets (10 $\mathrm{mL}$ of culture) were made and separated from culture medium by centrifugation (10 min at $3500 \mathrm{rpm}$ ). Pellets were rinsed in $2 \mathrm{ml}$ of assay buffer (150 nM NaCL, 3.2 mM KCL, $1.25 \mathrm{mM} \mathrm{MgSO}_{4}, 3.75$ $\mathrm{mM} \mathrm{CaCl}_{2}$, and $12.2 \mathrm{mM}$ TRIS base; $\mathrm{pH}$ adjusted to 7.4 with HCL) to remove remnants of $f / 2$ medium. To make algal extracts, cell pellets were disintegrated in $2 \mathrm{~mL}$ of assay buffer using a pulse sonicator with a $70 \%$ duty cycle for $2 \mathrm{~min}$. Algae extracts were maintained in ice during and after sonication.

\section{ERythrocyte LySIS ASSAY}

Prior to haemolytic bioassays, Alsevers anticoagulant was removed from chicken RBCs. Samples of RBCs $(250 \mu \mathrm{L})$ were suspended in $50 \mathrm{~mL}$ of assay buffer. These suspensions of erythrocytes were centrifuged $\left(10 \mathrm{~min}\right.$ at $3500 \mathrm{rpm}$ at $\left.4{ }^{\circ} \mathrm{C}\right)$ twice in $50 \mathrm{~mL}$ of assay buffer, and the supernatant was discarded. Rinsed RBCs without anticoagulant were added to $50 \mathrm{~mL}$ of assay buffer and yielded $\sim 2.50 \times 10^{6}$ cells $\mathrm{mL}^{-1}$. This suspension of erythrocytes was used in bioassays, and $5 \mathrm{~mL}$ was used to prepare separately positive and negative controls. Positive controls were prepared by sonication ( $2 \mathrm{~min}$ in a $70 \%$ duty cycle) to produce $100 \%$ lysis, whereas incubated erythrocytes $(18 \mathrm{~h})$ in assay buffer alone were considered negative controls. To determine the effect of potential haemolytic compounds on RBC algal extracts were titrated in bioassay to estimate the percentage of haemolytic activity at different cell concentrations. Assays of RBCs combined with algal extracts were carried out in triplicate ( $5 \mathrm{~mL}$ each) using $15 \mathrm{~mL}$ centrifuge tubes. Haemolytic assays were incubated in the dark at $20^{\circ} \mathrm{C}$ for $18 \mathrm{~h}$. Tubes were centrifuged at $4^{\circ} \mathrm{C}$ for $10 \mathrm{~min}$ (3000 rpm) after incubation, and $3 \mathrm{~mL}$ samples were used to determine absorption measurements by spectrophotometry (ATI UNICAM 8625 UV/VIS) at $415 \mathrm{~nm}$. Saponin (Sigma-Aldrich 84510) was used in this study as a chemically defined haemolytic agent (Eschbach et al. 2001). The haemolytic activity of algal compounds produced by $A$. cf. carterae and C. monotis was determined based on a reference curve of RBC lysis induced at different concentrations of saponin (Fig. 1). Saponin concentrations ranged from 1 to $50 \mu \mathrm{g} \mathrm{mL}^{-1}$, and complete lysis (100\%) of chicken RBCs was determined at $6 \mu \mathrm{g} \mathrm{mL}^{-1}$.

\section{COPEPOd BIOASSAYS}

The effect of potential toxicity was determined by the mortality of the harpacticoid copepod Tigriopus californicus (Reefphyto Ltd, Bristol, UK) that was cultured in 10 L flasks of filtered seawater $(0.22 \mu \mathrm{m})$, with salinities of $28-31$, for a period of 34 weeks. Copepod cultures were grown in the laboratory (at room temperature of $14-20^{\circ} \mathrm{C}$ ) in the shade with a natural photoperiod of daylight. Tigriopus californicus was grown in vitro for a period of 3-4 weeks. Copepods were fed in a culture of mixed chlorophytes, diatoms and cyanobacteria provided by Reefphyto Ltd, Bristol, England, UK. Young adult copepods 


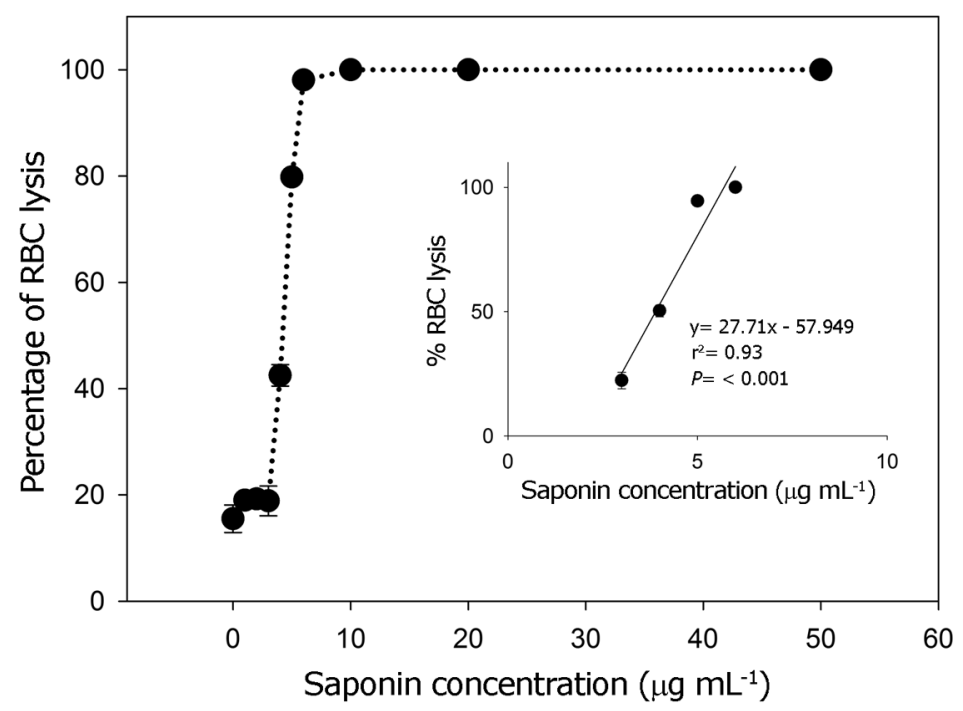

Figure 1. Calibration curve standardized to percentage of RBC lysis at different concentrations of saponin (dotted line and black circles) and linear regression based on haemolytic activity of RBC (inner plot) / Curva de calibración estandarizada a porcentaje de lisis de eritrocitos bajo diferentes concentraciones de saponina (línea punteada y círculos negros) y regresión lineal basada en la actividad hemolítica de las células rojas (gráfica interior)

were used in feeding bioassays. Specimens were isolated from cultures by filtering 2-3 L of water using a net mesh $(100 \mu \mathrm{m})$. Copepods were briefly rinsed $(<30 \mathrm{~s})$ with distilled water on the mesh to remove debris and food material from their bodies. There was no evidence that copepods were affected by rinsing. Copepods were kept in clean and filtered seawater $(0.2 \mu \mathrm{m})$ for 5 days without food before testing. Mortality of copepods was tested in 96-well plates (Thermo Scientific Nunc, USA). Bioassays tested 6 abundance treatments of the cultured species were as follows: $2.45,6.12,12.2,30.6,61.2$ and $122.2\left(\times 10^{3}\right)$ cells $\mathrm{mL}^{-1}$ for $A$. cf. carterae and $0.11,0.26,0.53,1.31,2.62$, $5.24\left(\times 10^{3}\right)$ cells $\mathrm{mL}^{-1}$ for $C$. monotis. Six replicates of each cell treatment were tested, and average mortality was expressed as a percentage. One replicate contained one starved copepod per well. Mortality assays of $A$. cf. carterae and $C$. monotis lasted 9 and 12 days, respectively.

\section{Statistical analyses}

Calculated growth rates and $F v / F m$ values were tested for statistical differences using one-way analysis of variance (ANOVA). The software SigmaPlot version 12.3 was used for all statistical analyses including tests of multiple comparisons in the range of growth temperatures $\left(5-30^{\circ} \mathrm{C}\right)$.

\section{SCANNING ELECTRON MiCROSCOPY}

A volume of $50 \mathrm{~mL}$ of $A$. cf. carterae $\left(10^{5}\right.$ cells $\left.\mathrm{mL}^{-1}\right)$ and 100 $\mathrm{mL}$ of $C$. monotis $\left(10^{4}\right.$ cells $\left.\mathrm{mL}^{-1}\right)$ at late exponential growth phase were concentrated by centrifugation for 15 min at 950 rpm. Supernatant was removed, and cell pellets were fixed in $1.5 \mathrm{ml}$ of $0.1 \mathrm{M}$ PIPES buffer (1,4 Piperazine bis (2ethanosulfonic acid, $\mathrm{pH}$ 7.2) combined with glutaraldehyde (3\%) and formaldehyde (4\%). Cells were maintained at $4{ }^{\circ} \mathrm{C}$ for $24 \mathrm{~h}$ during fixation. Fixed cells were transferred to silicate coated cover slips by pipetting. Cells were left to settle on the cover slips for $20 \mathrm{~min}$. Cover slips were rinsed twice in $0.1 \mathrm{M}$ PIPES buffer. Samples were dehydrated in series of graded ethanol concentrations $(30,50,70,95$, and $100 \%)$ for $10 \mathrm{~min}$ each. Samples were freeze-dried in a critical point dryer, mounted on stubs, and sputter coated for 10-15 min before scanning electron microscope (SEM) observations with a FEI Quanta 2000 SEM at 10-15 kV. Microscopy was carried out at the Biomedical Imagining Unit at the University of Southampton.

\section{Results}

The harmful benthic dinoflagellates Amphidinium cf. carterae and Coolia monotis were successfully grown in monocultures at temperatures between 5 and $30^{\circ} \mathrm{C}$. Microscopic observations of cultured cells and SEM microphotographs of $A$. cf. carterae and $C$. monotis determined distinctive features of the taxa in study (Fig. 2). 

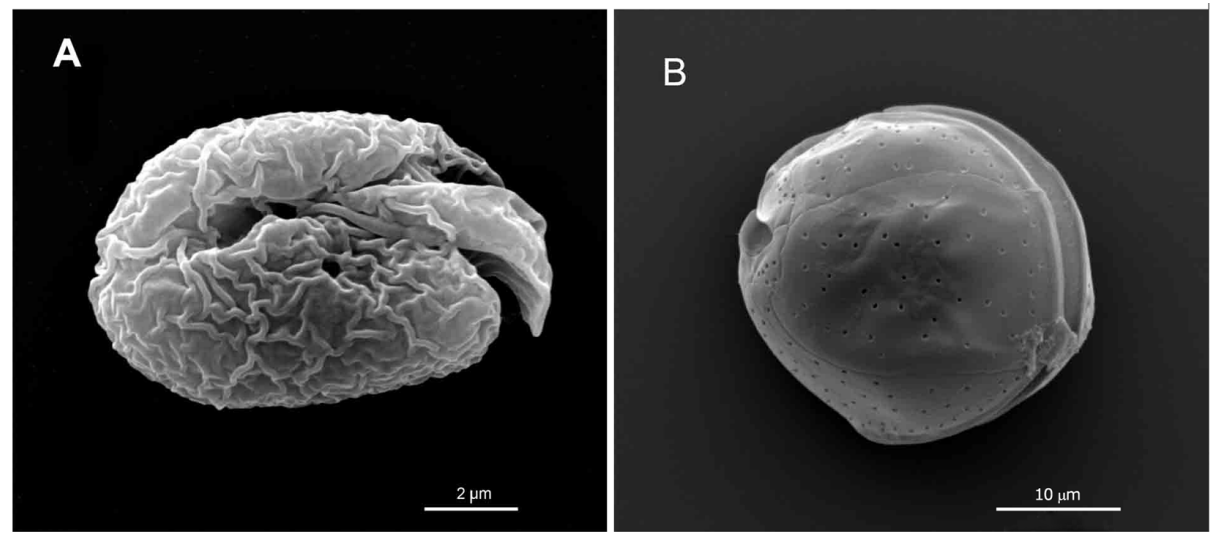

Figure 2. Scanning electron micrographs: Amphidinium cf. carterae (A) and Coolia monotis (B) clonal cells isolated from shallow waters of the Fleet Lagoon, Dorset, United Kingdom / Micrografías electrónicas de barrido de células clonales de Amphidinium cf. carterae (A) y Coolia monotis (B) aisladas de aguas someras del Fleet Lagoon, Dorset, Reino Unido
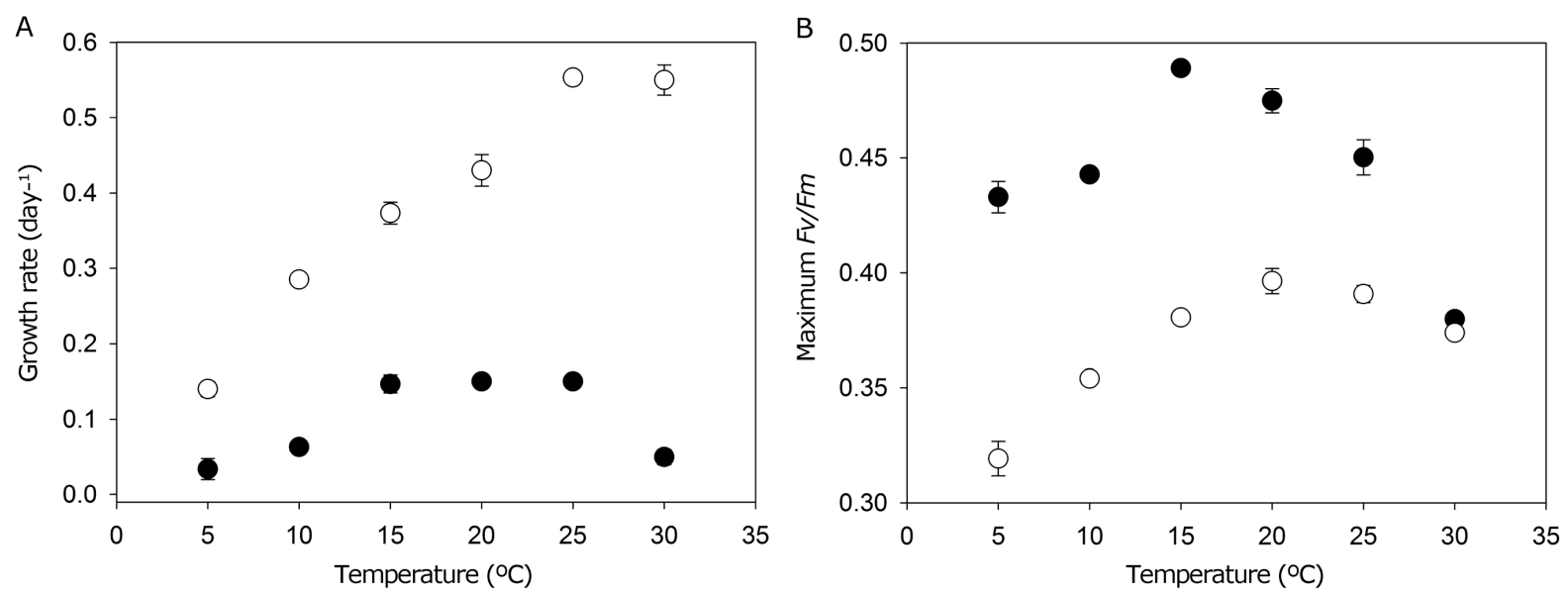

Figure 3. Changes in cell growth rates (A) and maximum photosynthetic efficiency ( $F v / F m)(B)$ in Amphidinium cf. carterae (white circles) and Coolia monotis (black circles) cultures grown at increasing water temperatures between $\mathbf{5}$ and $\mathbf{3 0} 0^{\circ} \mathrm{C} /$ Cambios en las tasas de crecimiento (A) y el máximo de eficiencia fotosintética (Fv/Fm) (B) en monocultivos de Amphidinium cf. carterae (círculos blancos) y Coolia monotis (círculos negros) al aumentar la temperatura entre 5 y $30^{\circ} \mathrm{C}$

\section{GRowth RATES AND $\boldsymbol{F} \boldsymbol{V} / \boldsymbol{F}_{M}$}

Optimum growth temperature differed between $A$. cf. carterae and $C$. monotis. The former reached its highest growth rate $\left(0.5\right.$ day $\left.^{-1}\right)$ at the most elevated temperatures $\left(25-30^{\circ} \mathrm{C}\right)$, while the latter had an optimum growth rate of 0.15 day $^{-1}$ between 15 and $25^{\circ} \mathrm{C}$. A. cf. carterae cultures exhibited higher growth rates (2.5-11 times, 0.1 day $^{-1}$ every $5^{\circ} \mathrm{C}$ ) than those of $C$. monotis as water temperature increased. Therefore, growth rates of $A$. cf. carterae proved to be statistically different ( $P=$ 0.05 ) from those in $C$. monotis cultures (Fig. 3). The highest water temperature $\left(30^{\circ} \mathrm{C}\right)$ induced significant growth and $F v /$ Fm impairment in C. monotis cells (Fig. 3) compared to values at the optimum growth temperatures $\left(15-25^{\circ} \mathrm{C}\right)$. Also, declining $F v / F m$ values throughout the stationary growth phase were indicative of poor photosynthetic performance in cultures of both species. Cultures of $A$. cf. carterae changed two orders of magnitude $\left(10^{3}\right.$ to $10^{5}$ cell $\left.\mathrm{mL}\right)$ in cell abundance at temperatures above $10^{\circ} \mathrm{C}$, while $C$. monotis cell concentration changed only an order of magnitude in the range of growth temperatures. The elevation of water temperature caused increasing $\mathrm{Fv} / \mathrm{Fm}$ values in A. cf. carterae and $C$. monotis (Fig. 3). Moreover, the exponential growth phase was characterized by increasing $F v / F m$ values in both species 

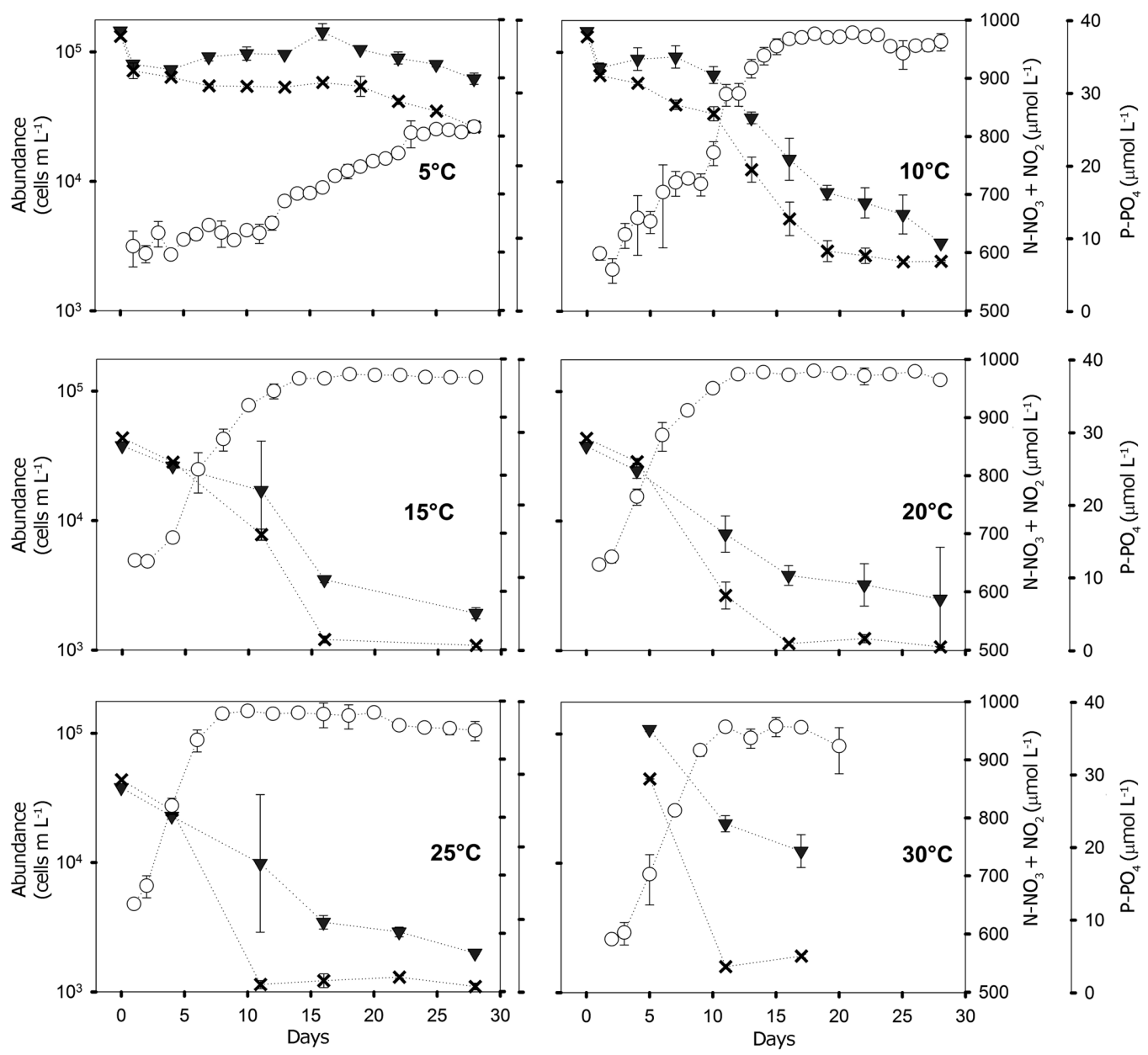

Figure 4. $\mathrm{N}-\mathrm{NO}_{3}+\mathrm{NO}_{2}$ (black triangles) and $\mathrm{P}-\mathrm{PO}_{4}$ (black crosses) consumption ( $\mu \mathrm{mol} \mathrm{L}^{-1}$ ) during the cell growth (white circles) of Amphidinium cf. carterae in cultures maintained in $\mathrm{f} / 2$ medium at growth temperatures between 5 and $30^{\circ} \mathrm{C} /$ Consumo de $\mathrm{N}-\mathrm{NO}_{3}+\mathrm{NO}_{2}$ (triángulos negros) y $\mathrm{P}_{-} \mathrm{PO}_{4}$ (cruces negras) ( $\mu$ moles $\mathrm{L}^{-1}$ ) durante el crecimiento celular (círculos blancos) de Amphidinium cf. carterae en cultivos mantenidos en medio $\mathrm{f} / 2$ a temperaturas de crecimiento entre 5 y $30^{\circ} \mathrm{C}$

cultures. Peaks of $F v / F m$ occurred towards the late exponential growth phase. Highest $F v / F m$ values mismatched the optimum growth temperature in both species (Fig. 3). However, $F v / F m$ values in $A$. cf. carterae cells did not prove to be statistically different at growth temperatures between $15-30^{\circ} \mathrm{C}$, despite differences in growth rates (Fig. 3). Surprisingly, $F v / F m$ values in $C$. monotis cells were statistically different at all growth temperatures $(P<0.001)$, even within the range of optimum growth temperature $\left(15-25^{\circ} \mathrm{C}\right)$ during the exponential growth phase for both species (Figs. 4-5). Despite having lower growth rates, $F v / F m$ values in $C$. monotis were higher than those in A. cf. carterae, except at $30^{\circ} \mathrm{C}$ (Fig. 3).

\section{Nutrients}

High consumption of nutrients $\left(\mathrm{N}-\mathrm{NO}_{3}+\mathrm{N}-\mathrm{NO}_{2}\right.$ and $\left.\mathrm{P}-\mathrm{PO}_{4}\right)$ occurred as a result of increasing temperature from 5 to $25^{\circ} \mathrm{C}$, particularly during the exponential growth phase of both species (Figs. 4 and 5). The most elevated temperature $\left(30^{\circ} \mathrm{C}\right)$ caused the lowest nutrient consumption for $A$. cf. carterae despite being linked to the range of optimum growth $\left(25-30^{\circ} \mathrm{C}\right)$. The highest $\mathrm{N}-\mathrm{NO}_{3}+\mathrm{N}-\mathrm{NO}_{2}$ and $\mathrm{P}-\mathrm{PO}_{4}$ consumption occurred at water temperatures between 20 and $25^{\circ} \mathrm{C}$ (Figs. 4 and 5). A. cf. carterae and $C$. monotis had no nitrogen deprivation during growth because $\mathrm{N}-\mathrm{NO}_{3}+\mathrm{N}-\mathrm{NO}_{2}$ concentrations were never below $500 \mu \mathrm{mol} \mathrm{L} \mathrm{L}^{-1}$ within the range of growth temperatures (Figs. 4 and 5). Therefore, the initiation of the stationary growth phase was not a consequence of $\mathrm{N}-\mathrm{NO}_{3}+\mathrm{N}-\mathrm{NO}_{2}$ availability. 

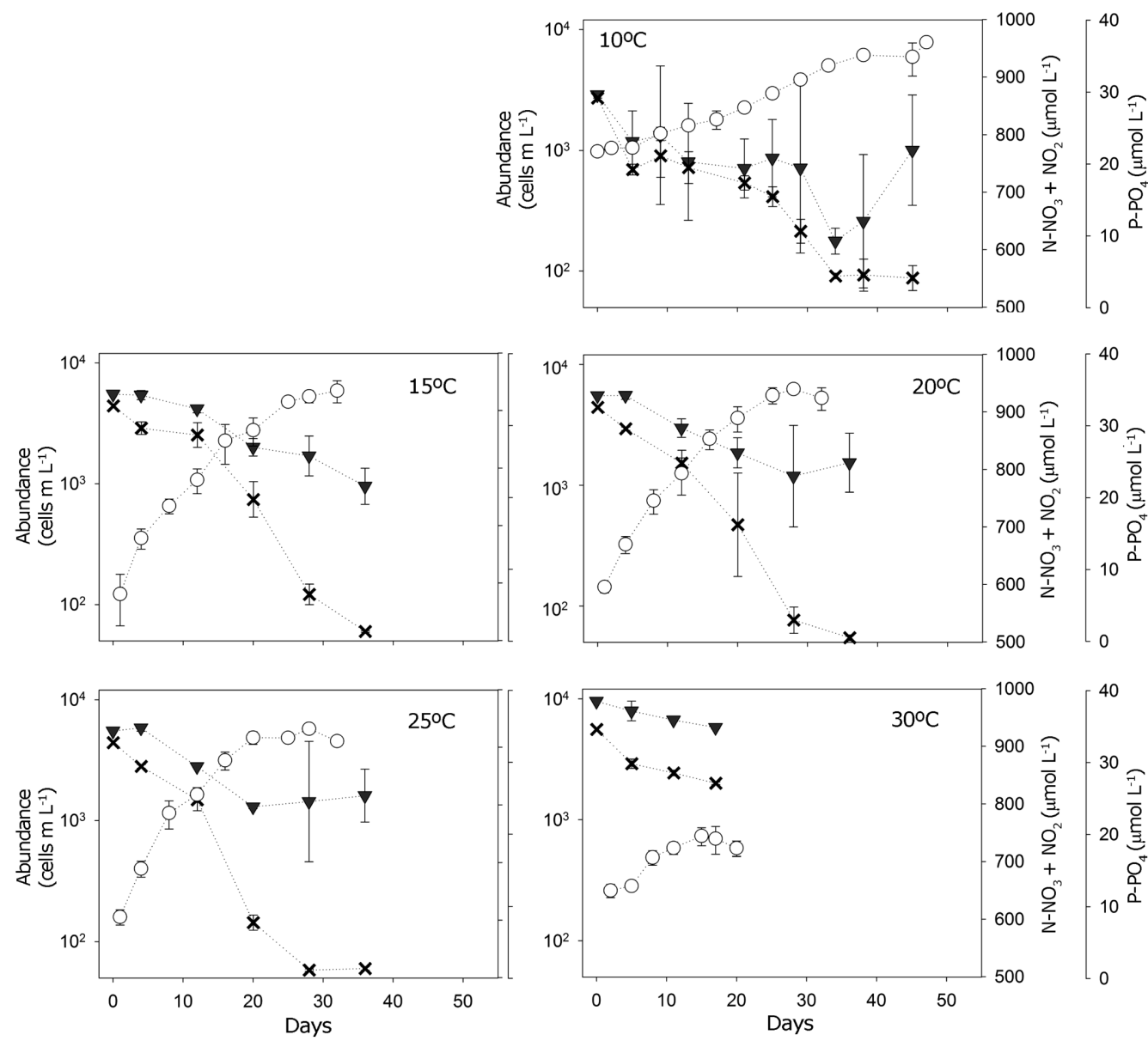

Figure 5. $\mathrm{N}-\mathrm{NO}_{3}+\mathrm{NO}_{2}$ (black triangles) and $\mathrm{P}-\mathrm{PO}_{4}$ (black crosses) removal ( $\mu \mathrm{mol} \mathrm{L-1}$ ) during the cell growth (white circles) of Coolia monotis in cultures grown in $\mathrm{f} / 2$ medium at growth temperatures between 5 and $30^{\circ} \mathrm{C} /$ Consumo de $\mathrm{N}-\mathrm{NO}_{3}+\mathrm{NO}_{2}$ (triángulos negros) y $\mathrm{P}-\mathrm{PO} \mathrm{O}_{4}$ (cruces negras) ( $\mu$ moles $\mathrm{L}^{-1}$ ) durante el crecimiento celular (círculos negros) de Coolia monotis en cultivos crecidos en medio $\mathrm{f} / 2 \mathrm{a}$ temperaturas de crecimiento entre 5 y $30^{\circ} \mathrm{C}$

$\mathrm{P}-\mathrm{PO}_{4}$ limitation occurred during the stationary growth phase, particularly at culture temperatures between 15 and $25^{\circ} \mathrm{C}$ (Figs. 4 and 5). Furthermore, $\mathrm{P}_{-} \mathrm{PO}_{4}$ limitation was recorded earlier in A. cf. carterae ( day 10) than in C. monotis cultures (days 28-36) at the optimum cell growth temperatures. During exponential cell growth, $\mathrm{N}-\mathrm{NO}_{3}+\mathrm{N}-\mathrm{NO}_{2} / \mathrm{P}-\mathrm{PO}_{4}$ ratios in both species were lower than the Redfield $\mathrm{N}-\mathrm{NO}_{3}+\mathrm{N}-\mathrm{NO}_{2} / \mathrm{P}-\mathrm{PO}_{4}$ ratio (16:1) and decreased at higher temperatures (Table 1). $\mathrm{N}-\mathrm{NO}_{3}+\mathrm{N}-\mathrm{NO}_{2}$ and $\mathrm{P}-\mathrm{PO}_{4}$ consumption per cell was calculated for both species, but results did not show a pattern of higher removal at increasing water temperatures (Fig. 6). Surprisingly, highest $\mathrm{N}-\mathrm{NO}_{3}+\mathrm{N}-\mathrm{NO}_{2}$ and $\mathrm{P}-\mathrm{PO}_{4}$ consumption per cell was not related to the optimum growth temperature for both dinoflagellate taxa (Fig. 6). Nutrient analyses proved to be highly variable in $C$. monotis cultures at $5^{\circ} \mathrm{C}$ and are not shown in this study.
Table 1. $\mathrm{N}-\mathrm{NO}_{3}+\mathrm{N}-\mathrm{NO}_{2} / \mathrm{N}-\mathrm{PO}_{4}$ ratio values \pm standard deviation (SD) determined during the exponential growth phase of $A$. cf. carterae and $\mathrm{C}$. monotis at temperatures between 5 and $30^{\circ} \mathrm{C}$. Values ( \pm SD) were obtained from duplicate $(* *)$ and triplicate $(* * *)$ cultures / Proporciones de $\mathrm{NO}_{3}+\mathrm{NO}_{2} / \mathrm{PO}_{4}$ determinadas durante la fase de crecimiento exponencial de $\mathrm{A}$. cf. carterae y $\mathrm{C}$. monotis a temperaturas entre 5 y $30^{\circ} \mathrm{C}$; los valores ( $\left.\pm S D\right)$ se obtuvieron de cultivos en duplicado $\left({ }^{* *}\right)$ y triplicado $\left({ }^{* * *}\right)$

\begin{tabular}{ccc}
\hline \multirow{2}{*}{$\begin{array}{c}\text { Temperature } \\
\left({ }^{\circ} \mathrm{C}\right)\end{array}$} & \multicolumn{2}{c}{$\mathrm{NO}_{3}+\mathrm{NO}_{2} / \mathrm{PO}_{4}$ ratios } \\
\cline { 2 - 3 } & A. cf. carterae & C. monotis \\
\hline 5 & $16,9( \pm 2,33)^{* *}$ & - \\
10 & $10,0( \pm 0,70)^{* *}$ & $9,1( \pm 0,95)^{* * *}$ \\
15 & $8,2( \pm 0,35)^{* * *}$ & $7,0( \pm 0,21)^{* * *}$ \\
20 & $7,0( \pm 0,78)^{* * *}$ & $5,3( \pm 0,24)^{* * *}$ \\
25 & $4,3( \pm 3,09)^{* * *}$ & $5,4( \pm 0,02)^{* * *}$ \\
30 & $9,7( \pm 1,48)^{* *}$ & $10,3( \pm 3,86)^{* *}$ \\
\hline
\end{tabular}



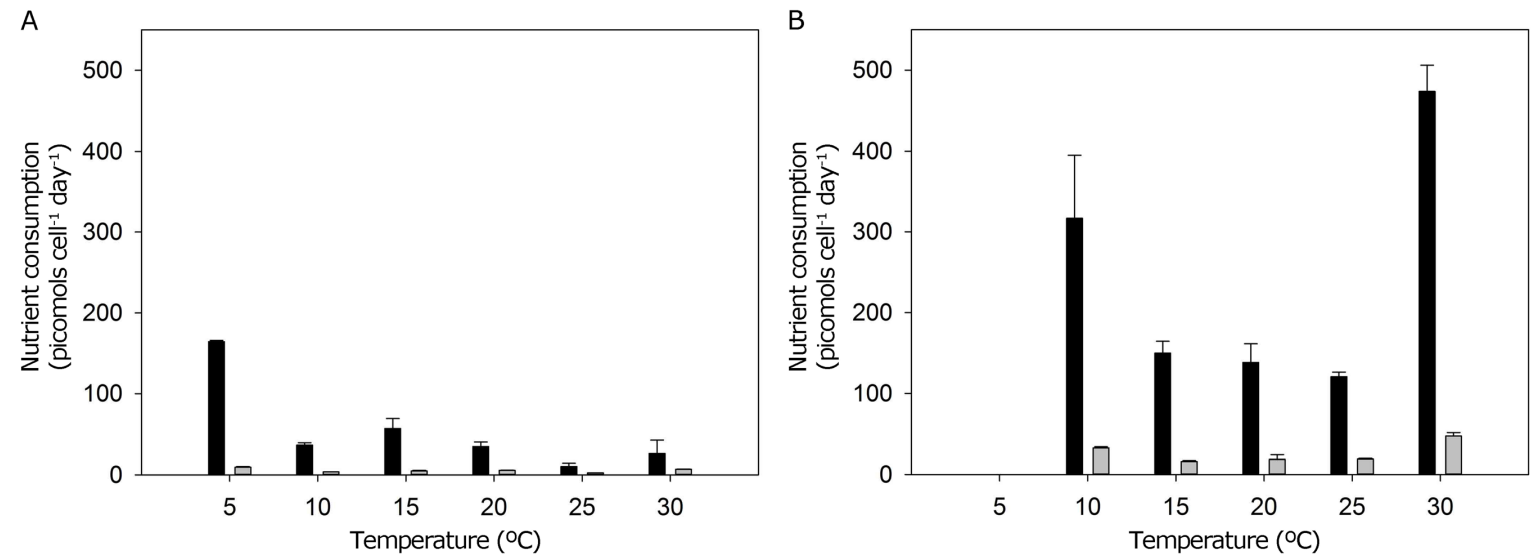
Figure 6. Calculated $\mathrm{N}-\mathrm{NO}_{3}+\mathrm{NO}_{2}$ (black bars) and $\mathrm{P}-\mathrm{PO}_{4}$ (gray bars) cell consumption (picomols cell ${ }^{-1}$ day $^{-1}$ ) during the exponential cell growth
of Amphidinium cf. carterae $\left(\mathbf{A}\right.$ ) and Coolia monotis $(\mathbf{B})$ at water temperatures between 5 and $30^{\circ} \mathrm{C} /$ Cálculo del consumo celular de $\mathrm{N}-$
$\mathrm{NO}_{3}+\mathrm{NO}_{2}$ (barras negras) y $\mathrm{P}-\mathrm{PO}_{4}$ (barras grises) (picomoles cél ${ }^{-1}$ día ${ }^{-1}$ ) durante el crecimiento exponencial de Amphidinium cf. carterae y Coolia monotis a temperaturas entre 5 y $30^{\circ} \mathrm{C}$

\section{COPEPOD MORTALITY}

The harpacticoid copepod Tigriopus californicus was fed with a wide range of $A$. cf. carterae and $C$. monotis cell abundances for 10 and 12 days, respectively. All the treatments showed high mortality percentages, suggesting harmful effects of both benthic dinoflagellates (Fig. 7). However, the effect of increasing A. cf. carterae abundance $\left(24.5 \times 10^{2}-122.5 \times 10^{3}\right.$ cell $\left.\mathrm{mL}^{-1}\right)$ in the feeding assay did not cause either higher or faster mortality of $T$. californicus. High mortality rates (50-100\%) from A. cf. carterae ingestion occurred from day 4 onwards, but, surprisingly, the most elevated cell abundances (61.2 and $122.5 \times 10^{3}$ cell $\mathrm{mL}^{-1}$ ) only caused 50 and $83 \%$ mortality, respectively (Fig. 7). Feeding assays supplemented with $C$. monotis caused higher mortality as cell abundance increased. Even at low abundance, $C$. monotis caused $>50 \%$ mortality on day 7 while higher concentrations resulted in $100 \%$ mortality as early as on day 5. Control tests of T. californicus (fed on non-toxic algae) reached a maximum mortality of $33.3 \%$ (day 10) and $16.6 \%$ (day 12) at the end of the feeding assays of $A$. cf. carterae and C. monotis, respectively (Fig. 7).

\section{HAEMOLYTIC ACTIVITY ON ERYTHROCYTES}

The detection and lytic activity of haemolytic compounds from $A$. cf. carterae and C. monotis were assessed on chicken erythrocytes with crude microalgal extracts at different cell concentrations. Higher haemolytic activity was recorded at increasing cell concentrations for both species after an incubation period of $18 \mathrm{~h}$ at a temperature of $\sim 20^{\circ} \mathrm{C}$ (Fig. 8). Highest haemolytic activity (95-100\%) occurred when erythrocytes were exposed to $0.5-2.0 \times 10^{6}$ cell $\mathrm{mL}^{-1}$ of $A$. cf. carterae. Maximum lytic response was $70 \%$ with $C$. monotis extracts at the most elevated cell abundances $\left(3.0 \times 10^{4}\right.$ cell $\mathrm{mL}^{-1}$, Fig. 8$)$. Negative controls (erythrocytes without algae extracts) had lower lysis and values recorded after the incubation period (see above) and were subtracted from results of haemolytic assays with algae extracts.

\section{Discussion}

The raising of water temperature in combination with higher nutrient loads in aquatic coastal ecosystems is envisaged to potentially increase the occurrence of future HAB events worldwide (Peperzak 2003, Hallegraeff 2010), particularly in shallow coastal environments, e.g., the Fleet Lagoon, Dorset, south of England. Here, two temperate-tropical potentially toxic benthic dinoflagellates, $A$. cf. carterae and $C$. monotis, were grown in monocultures at water temperatures between 5 and $30^{\circ} \mathrm{C}$. Both species survived and grew along the regime of water temperatures with optimal growth rates linked to both increasing water temperatures and replete nutrient conditions. These benthic dinoflagellates have been found in tropical, subtropical and temperate coastal waters around the world (Morton et al. 1992, Ignatiades \& Gotsis-Skretas 2010, Gárate-Lizárraga 2012), particularly in coastal marine environments with mesotrophic and eutrophic waters (Aquino-Cruz 2012, Ismael $\&$ Halim 2012), although at present tropical findings of $C$. monotis are in doubt (Momigliano et al. 2013). Many benthic dinoflagellates are confined to tropical waters, suggesting that temperature may be a primary influence on growth and 

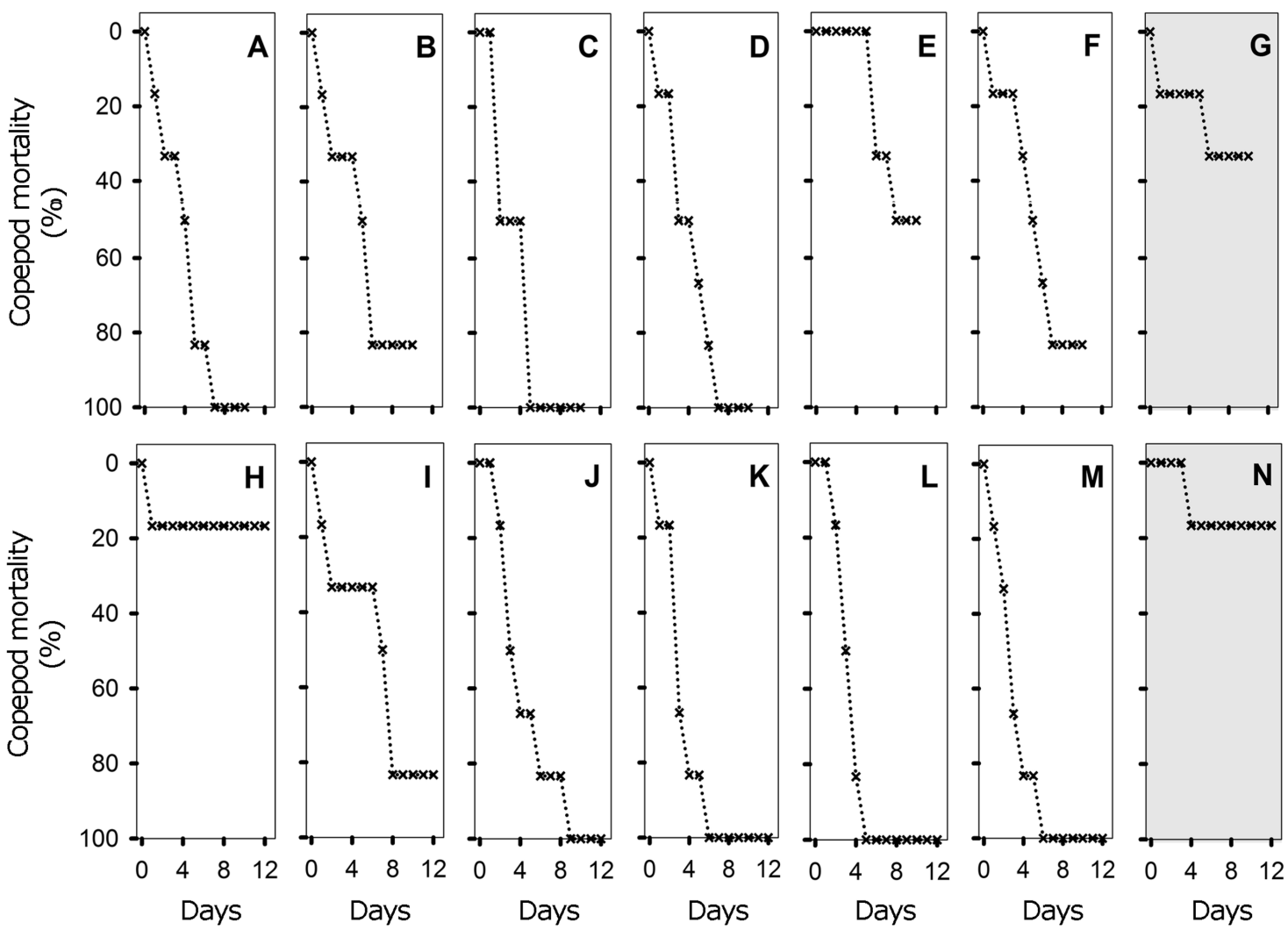

Figure 7. Mortality of the harpacticoid copepod Tigriopus califonicus fed on increasing microalgal concentrations of Amphidinium cf. carterae (A: 2.45,

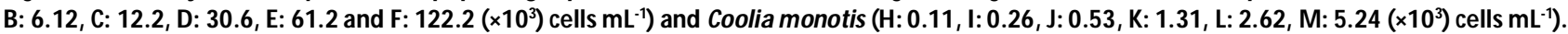
Right panel (gray color) shows bioassay controls (T. californicus fed on non-toxic microalgae) of A. cf. carterae (G) and C. monotis (N). Six replicates were assessed at each cell concentration / Mortalidad del copépodo harpacticoide Tigriopus californicus alimentado con concentraciones microalgales en aumento de Amphidinium cf. carterae (A: 2.45, B: 6.12, C: 12.2, D: 30.6, E: 61.2 y F: $122.2\left(\times 10^{3}\right)$ cél mL-1) y Coolia monotis (H: 0.11, I: 0.26, J: 0.53 , K: 1.31, L: 2.62, M: $5.24\left(\times 10^{3}\right)$ cél $\mathrm{mL}^{-1}$ ). Los paneles de la derecha (color gris) muestran los controles de los bioensayos, T. californicus alimentado con microalgas no tóxicas, para A. cf. carterae (G) y C. monotis (N). Seis replicados fueron evaluados a cada concentración celular

Figure 8. Haemolytic activity of chicken erythrocytes incubated with algal extracts prepared from Amphidinium cf. carterae (black circles) and Coolia monotis (white circles) cells at different abundances / Actividad hemolítica de eritrocitos de pollo incubados con extractos algales de Amphidinium cf. carterae (círculos negros) y Coolia monotis (círculos blancos) preparados con diferentes densidades celulares

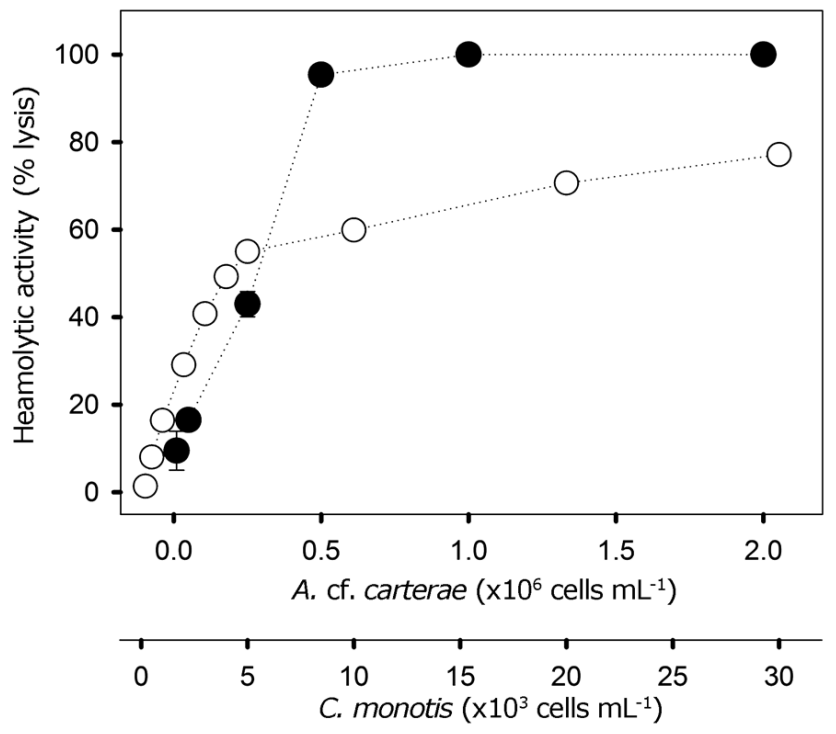


distribution (Taylor et al. 2003). The Fleet Lagoon is an eutrophic coastal system with several nutrient loadings, e.g., mainly cultivated agriculture $(>80 \%)$ and livestock (Weber $e t$ al.2006), where changes in temperature and nutrient availability may be suitable for harmful events of $A$. cf. carterae and $C$. monotis. Of all harmful events caused by dinoflagellates in the Fleet Lagoon, there has been no evidence of an association between higher water temperature and nutrient availability in the development of HABs of $A$. cf. carterae and C. monotis in this area (Hinder et al. 2011, Davidson \& Bresnan 2009). HABs of benthic dinoflagellates in the Fleet Lagoon have occurred, but they were commonly ascribed to the genus Prorocentrum (Foden et al. 2005, Nascimento et al. 2005).

The most elevated temperatures $\left(25\right.$ and $\left.30^{\circ} \mathrm{C}\right)$ in this study caused optimal growth rates of $A$. cf. carterae and $C$. monotis. The Fleet Lagoon has been found with surface water temperatures $\sim 25^{\circ} \mathrm{C}$ during summer (Nascimento 2003) that may provide suitable growth conditions for HAB species. Amphidinium cf. carterae had high tolerance to elevated temperatures $\left(25-30^{\circ} \mathrm{C}\right)$, suggesting an ecological advantage over other harmful benthic dinoflagellates, such as $C$. monotis and Prorocentrum lima (Nascimento 2003), in coping with warm conditions in the Fleet Lagoon. Here, warm conditions enhanced the growth rate of $A$. cf. carterae, but some strains of the genus Amphidinium Clap. et Lachm. have shown decreasing growth rates at temperatures of $31-35^{\circ} \mathrm{C}$ (Morton 1992). Lee et al. (2003) also reported that sustained temperatures above $34^{\circ} \mathrm{C}$ resulted in death (lysed cells) of $A$. cf. carterae. In tropical waters of the Veracruz reef zone, $A$. cf. carterae has been shown to be present throughout the year at water temperatures ranging from 24 to $32^{\circ} \mathrm{C}$, with highest abundance peaking at the water temperature of $32^{\circ} \mathrm{C}$ in late spring (Okolodkov et al. 2007). In the southern Gulf of California, Gárate-Lizárraga (2012) reported a pelagic bloom caused by $A$. cf. carterae at $20^{\circ} \mathrm{C}$. Here, $A$. cf. carterae not only could grow at elevated temperatures, but also could sustain continuous cell growth at $5^{\circ} \mathrm{C}$. This shows a remarkable physiological adaptability of the species for colonization and survival in diverse habitats from warmer tropical to temperate or even colder coastal waters. Generally, physical conditions in microalgal cultures vary, and therefore comparison of growth dynamics between strains can be complicated (Lakeman et al. 2009). Table 2 compares culture conditions and growth rates of $A$. cf. carterae reported in the literature. Even though some microalgae exhibit a rapid adaptability to high temperatures in short-term experiments, the physiological plasticity and genetic response of many microalgae under future environmental conditions is unknown (Hallegraeff 2015). Also, complex physical interactions $\left(\mathrm{CO}_{2}\right.$ dissolution, light, nutrient diffusion, stratification, atmospheric precipitation, and salinity) in the environment at higher temperatures have been insufficiently studied regarding the growth of many harmful microalgae (Hallegraeff 2010). Therefore, future studies should investigate physiological responses (adaptation) of microalgae in the environment, ideally taking into account long-term observations and experiments, to provide a better assessment of the impact of climate change on the growth of harmful dinoflagellates.

Increasing temperatures $\left(5-15^{\circ} \mathrm{C}\right)$ triggered higher growth rates of $C$. monotis, but no difference of growth occurred between 15 and $25^{\circ} \mathrm{C}$. These ranges of temperatures are common in waters of the Fleet Lagoon (Nascimento 2003) and could sustain blooms of $C$. monotis during favorable growth conditions. Growth experiments lasted a few weeks, and strains had a short period of acclimation between temperatures; therefore, we have not determined whether $C$. monotis might exhibit higher growth rates and adaptability at elevated temperatures in the future. In tropical waters of the Veracruz reef zone of the Gulf of Mexico, C. monotis was found throughout the year, with the highest abundance $\left(3.0 \times 10^{3}\right.$ cells $\mathrm{g}^{-1}$ seagrass Thalassia testudinium Banks ex Konig wet weight) in July at a water temperature of $\sim 28^{\circ} \mathrm{C}$ and a salinity of 29 (Okolodkov et al. 2007). Moreover, Armi et al. (2010) reported a bloom of $C$. monotis that occurred at temperatures higher than $22^{\circ} \mathrm{C}$ between May and July in Tunisian waters that contributed to almost half of the total phytoplankton abundance. Growth rates of $C$. monotis strains under different growth conditions are compared in Table 3.

$\mathrm{Fv} / \mathrm{Fm}$ (maximum quantum yield of PSII) is a valuable indicator of the physiological state of the cells when either nutrient stress or photoinhibition are experienced by phytoplankton (Moore et al. 2008, Suggett et al. 2009, From et al. 2014). Despite its lack of specificity, $F v / F m$ could adequately assess nutrient stress in phytoplankton when photoinhibition is not of concern (From et al. 2014). Knowledge of $F v / F m$ values of harmful benthic dinoflagellates is scarce, and comparing $F v /$ $F m$ data between strains may be difficult due to differences in culture conditions. Ecophysiological studies on photosynthesisirradiance relationships of one $A$. cf. carterae strain have shown a remarkable photoadaptability (light gradient $24-800 \mu \mathrm{E} \mathrm{m}^{-2}$ $\mathrm{s}^{-1}$ ) of this dinoflagellate, suggesting a biological strategy for prospering in shallow coastal waters (Gerath \& Chisholm 1989). This suggests a wide environmental window of the genus Amphidinium because a range of growth conditions (e.g., irradiances) have been linked to the optimum growth rate of different Amphidinium strains (see Table 2). Coolia monotis had higher $F v / F m$ values than $A$. cf. carterae, but growth rates of the former were significantly lower (see Fig. 3). Light history 
Table 2 Growth rates and conditions applied during the growth of different strains of $\mathbf{A}$. f. carterae; nd=no data available / Tasas de crecimiento y condiciones establecidas durante el crecimiento de diferentes cepas de A. cf. carterae; nd= datos no disponibles

\begin{tabular}{|c|c|c|c|c|c|c|c|c|}
\hline Species & $\begin{array}{l}\text { Growth rate } \\
\quad\left(\text { day }^{-1}\right)\end{array}$ & $\begin{array}{l}\text { Temperature } \\
\left({ }^{\circ} \mathrm{C}\right)\end{array}$ & $\begin{array}{c}\text { Light } \\
\left(\mu \mathrm{mol} \mathrm{m}{ }^{-2} \mathrm{~s}^{-1}\right)\end{array}$ & Salinity & $\begin{array}{l}\text { Max. cell } \\
\text { density } \\
\left(\text { cells ml }{ }^{-1}\right)\end{array}$ & Culture medium & $\begin{array}{l}\text { Location of } \\
\text { isolation }\end{array}$ & Reference \\
\hline $\begin{array}{c}\text { Amphidinium } \\
\text { carterae }\end{array}$ & nd & 25 & $56-112$ & nd & $1.9 \times 10^{5}$ & $\begin{array}{l}\text { SW plus } \\
\text { Provasoli's ES } \\
\text { supplement }\end{array}$ & Okinawa, Japan & $\begin{array}{c}\text { Nakajima et al. } \\
1981\end{array}$ \\
\hline A. carterae & $0.39-0.44$ & 15 & $\begin{array}{c}70 \\
1\end{array}$ & 30 & nd & $\mathrm{f} / 10$ & $\begin{array}{c}\text { Tjøme, outer } \\
\text { Oslofjord }\end{array}$ & $\begin{array}{c}\text { Sakshaug et al. } \\
1983\end{array}$ \\
\hline A. carterae & $\begin{array}{l}(27 \mathrm{~h} \\
\text { generation } \\
\text { time })\end{array}$ & 21 & $10-70$ & nd & nd & $\mathrm{f} / 2$ & nd & $\begin{array}{c}\text { Olson \& } \\
\text { Chisholm } 1986\end{array}$ \\
\hline A. carterae & 1 & 20 & $150-260$ & nd & $2 \times 10^{5}$ & $\mathrm{f} / 2$ & nd & $\begin{array}{c}\text { Gerath \& } \\
\text { Chisholm } 1989\end{array}$ \\
\hline Amphidinium klebsii & 0.45 & 27 & $\begin{array}{c}207 \\
(10 \% \text { sunlight })\end{array}$ & 33 & nd & $\mathrm{K}$ & $\begin{array}{l}\text { Knight Key, } \\
\text { Florida }\end{array}$ & $\begin{array}{c}\text { Morton et al. } \\
1992\end{array}$ \\
\hline A. carterae & nd & nd & 28 & nd & $5.17 \times 10^{5}$ & $\begin{array}{c}\text { Erdschreiber's } \\
\text { soil extract }\end{array}$ & Mangalore, India & Nayak et al. 1997 \\
\hline A. carterae & 0.47 & nd & nd & 30 & nd & $f / 2$ & nd & $\begin{array}{c}\text { Strom \& Morello } \\
1998\end{array}$ \\
\hline A. carterae & 2.7 & 25 & $41-48$ & nd & nd & $\operatorname{GPM}(2.5 \mathrm{X})$ & $\begin{array}{l}\text { Alexandria, } \\
\text { Egypt }\end{array}$ & Ismael et al. 1999 \\
\hline A. carterae & 0.5 & 20 & 100 & nd & nd & $\mathrm{f} / 2$ & nd & Jeong et al. 2003 \\
\hline Amphidinium sp. & 1 & $13.6-32.9$ & 100 & 38 & $5 \times 10^{5}$ & ASP 7 & nd & Lee et al. 2003 \\
\hline A. carterae & 0.4 & 16 & 200 & nd & $4-5 \times 10^{5}$ & $\begin{array}{l}\text { L1 with boric } \\
\text { acid, TRIS buffer, } \\
\text { and } \mathrm{Na}_{2} \mathrm{CO}_{3}\end{array}$ & CCAP, UK & $\begin{array}{c}\text { Franklin \& } \\
\text { Berges } 2004\end{array}$ \\
\hline A. carterae & $0.13-0.55$ & $5-30$ & $35-70$ & $28-33$ & $1.5 \times 10^{5}$ & $\mathrm{f} / 2$ & Fleet Lagoon, UK & This study \\
\hline
\end{tabular}


Table 3. Growth rates of $\mathrm{C}$. monotis determined under different experimental conditions; $\mathbf{n d}=$ no data available / Tasas de crecimiento de $\mathrm{C}$. monotis determinadas bajo diferentes condiciones experimentales; $\mathrm{nd}=$ datos no disponibles

\begin{tabular}{|c|c|c|c|c|c|c|c|c|}
\hline Species & $\begin{array}{l}\text { Growth rate } \\
\quad\left(\text { day }^{-1}\right)\end{array}$ & $\begin{array}{c}\text { Temperature } \\
\left({ }^{\circ} \mathrm{C}\right)\end{array}$ & $\begin{array}{l}\text { Light } \\
\left(\mu \mathrm{mol} \mathrm{m}^{-2} \mathrm{~s}^{-1}\right)\end{array}$ & Salinity & $\begin{array}{l}\text { Max. cell } \\
\text { density } \\
\left(\text { cells ml }{ }^{-1} \text { ) }\right.\end{array}$ & Culture medium & $\begin{array}{l}\text { Location of } \\
\text { isolation }\end{array}$ & Reference \\
\hline Coolia monotis & 0.15 & 33 & 243 & 33 & nd & $\begin{array}{l}\text { K (omitting } \\
\text { Tris, copper and } \\
\text { silica) }\end{array}$ & nd & $\begin{array}{l}\text { Morton et al. } \\
\quad 1992\end{array}$ \\
\hline C. monotis & 0.20 & 31 & 243 & 33 & nd & K & nd & $\begin{array}{l}\text { Morton et al. } \\
\quad 1992\end{array}$ \\
\hline C. monotis & 0.30 & 29 & 243 & 33 & nd & K & nd & $\begin{array}{l}\text { Morton et al. } \\
\quad 1992\end{array}$ \\
\hline C. monotis & 0.14 & 27 & 243 & 33 & nd & K & nd & $\begin{array}{l}\text { Morton et al. } \\
\quad 1992\end{array}$ \\
\hline C. monotis & 0.10 & 25 & 243 & 33 & nd & K & nd & $\begin{array}{l}\text { Morton et al. } \\
\quad 1992\end{array}$ \\
\hline C. monotis & 0.08 & 23 & 243 & 33 & nd & K & nd & $\begin{array}{l}\text { Morton et al. } \\
\quad 1992\end{array}$ \\
\hline C. monotis & 0.3 & 25 & 100 & 35 & nd & GP & $\begin{array}{l}\text { Northland, } \\
\text { New Zealand }\end{array}$ & $\begin{array}{l}\text { Rhodes et al. } \\
\quad 2000\end{array}$ \\
\hline C. monotis & $\begin{array}{l}\text { (10 days } \\
\text { doubling } \\
\text { time })\end{array}$ & 15 & 100 & 27 & nd & GP & $\begin{array}{l}\text { Northland, } \\
\text { New Zealand }\end{array}$ & $\begin{array}{l}\text { Rhodes et al. } \\
\quad 2000\end{array}$ \\
\hline C. monotis & $\begin{array}{c}\text { (3-4 days } \\
\text { doubling } \\
\text { time) }\end{array}$ & 23 & $30-90$ & 36 & $2.5 \times 10^{-3}$ & Erdschreiber's & $\begin{array}{l}\text { Twin Cays, } \\
\text { Belize }\end{array}$ & Faust 1992 \\
\hline C. monotis & $0.01-0.32$ & $5-30$ & $35-70$ & $28-33$ & $10.0 \times 10^{-3}$ & $\mathrm{f} / 2$ & $\begin{array}{c}\text { Fleet Lagoon, } \\
\text { UK }\end{array}$ & This study \\
\hline
\end{tabular}

signal (e.g., light saturation) or a lack of available reaction centers in small-celled dinoflagellate species may explain lower $F v / F m$ values encountered in $A$. cf. carterae (From et al. 2014). However, this study was limited to comprehension of the photochemistry (e.g., photoinhibition) in the taxa studied. Higher growth rates of $A$. cf. carterae may be explained by rapid metabolic processes of the species. Given that $A$. cf. carterae can store nutrients for several generations (Lee et al. 2003), cell division may occur in the same manner even though cells have deficiencies in Fv/Fm.

Higher $\mathrm{NO}_{3}+\mathrm{NO}_{2} / \mathrm{PO}_{4}$ ratios (24-27:1) were used in growth experiments, and as a result, $\mathrm{PO}_{4}$ limitation occurred and deterred cell division of the species, particularly at increasing temperatures $\left(15-25^{\circ} \mathrm{C}\right)$. Since nitrogen loads in the Fleet Lagoon have historically been higher than those of $\mathrm{PO}_{4}$, algal bloom formation (Weber et al. 2006), duration and permanency could be partially controlled by $\mathrm{PO}_{4}$ availability. In this study, $\mathrm{PO}_{4}$ limitation was thought to be the cause of lower $F v / F m$ values, but biological interpretation must be made cautiously since $F v / F m$ is not nutrient specific (Kromkamp \& Peene 1999).
Amphidinium cf. carterae (Ismael et al. 1999, Kobayashi \& Tsuda 2004, Ignatiades \& Gotsis-Skretas 2010, Mandal et al. 2011) and C. monotis (Nakajima et al. 1981, Holmes et al. 1995, Rhodes \& Thomas 1997, Sugg \& Van Dolah 1999) have been recognized as toxin-producing species. Daranas et al. (2001) and Kobayashi \& Tsuda (2004) have shown the chemical structure of about 20 potential toxins (amphidinolides) linked to $A$. cf. carterae. Moreover, antifungal and haemolytic compounds have been reported by Echigoya et al. (2005). The first toxin characterized from $C$. monotis was named cooliatoxin, but some studies have shown that not all strains are toxic (Penna et al. 2005, Laza-Martínez et al. 2011). In this study, bioassays on mortality of the copepod Tigriopus californicus and lysis of RBCs suggested the potential toxicity of the strains examined. However, results were limited in relating mortality rates to cell abundance, particularly in the $A$. cf. carterae bioassays. Similarly, Baig et al. (2006), using wild $\left(2.50 \times 10^{2}, 10^{3}, 10^{5}\right.$ cells $\left.\mathrm{ml}^{-1}\right)$ and cultured $\left(7.20 \times 10^{2}, 10^{3}\right.$, $10^{4}$ cells $\left.\mathrm{ml}^{-1}\right) A$. cf. carterae, failed to demonstrate a significant mortality effect on the brine shrimp Artemia salina (L.) in 
feeding experiments. Copepods possess highly sensitive and specific chemoreceptive and selective abilities that influence their grazing behavior (Teegarden \& Cembella 1996), and some may exhibit a substantial tolerance to ingestion of toxic algae (Senft et al. 2011). Discrepancies found in mortality rates may have been related to the combination of the toxic burden ingested and the potential toxin resistance of harpacticoid copepods. Teegarden \& Cembella (1996) commented that some toxins could undergo metabolic transformations in the guts of grazers whereby toxins become less harmful after ingestion.

In conclusion, harmful benthic dinoflagellates from shallow coastal waters may encounter suitable growth conditions as a result of water warming and higher nutrient availability. Global environmental changes and the dynamics of benthic microalgal populations should be assessed with long-term studies in vulnerable coastal areas. More information is needed regarding the mechanisms of toxicity of $A$. cf. carterae and $C$. monotis strains at higher trophic levels. In addition, knowledge of chemical transformations of biotoxins from benthic microalgae would be valuable.

\section{ACKNOWLEDGMENTS}

This study was funded by CONACyT (Consejo Nacional de Ciencia y Tecnología de México) through a PhD scholarship granted to AAC. Our thanks are to Mike Zubkov and Manuela Hartmann for all facilities provided in the Molecular and Ecology Laboratory of the National Oceanography Centre, Southampton, UK, and to Mark Stinchcombe for his assistance with nutrient analysis in the Biogeochemistry Laboratory of the NOCS. Donald W. Johnson (Fisheries Professional Emeritus, American Fisheries Society) and Marcia M. Gowing (University of California at Santa Cruz, California, USA) kindly improved the English style.

\section{LITERATURE CITED}

Aquino-Cruz A. 2012. Effect of increasing sea water temperature on the growth and toxin production of three harmful benthic dinoflagellates isolated from the Fleet Lagoon, Dorset, UK. PhD Thesis. University of Southampton, Southampton, Hampshire, 170 pp.

Armi Z, S Turki, E Trabelsi \& N Ben-Maiz. 2010. First recorded proliferation of Coolia monotis (Meunier, 1919) in the North Lake of Tunis (Tunisia) correlation with environmental factors. Environmental Monitoring and Assessment 164: 423-433.

Baig HS, SM Saifullah \& A Dar. 2006. Occurrence and toxicity of Amphidinium carterae Hulburt in the North Arabian Sea. Harmful Algae 5: 133-140.
Beardall J \& S Stojkovic. 2006. Microalgae under global environmental change: implications for growth and productivity populations and trophic flow. Science Asia 32: $1-10$.

Bresnan E, K Davidson, M Edwards, L Fernand, R Gowen, A Hall, K Kennington, A McKinney, S Milligan, R Raine \& J Silke. 2013. Impact of climate change on harmful algal blooms. MCCIP Science Review 2013: 236-243.

Daranas AH, M Norte \& JJ Fernandez. 2001. Toxic marine microalgae. Toxicon 39: 1101-1132.

Davidson K \& E Bresnan. 2009. Shellfish toxicity in UK waters: a threat to human health? Environmental Health 8: S1-S12.

De Vicente J, JR Huckins \& SD Rychnovsky. 2006. Synthesis of the C31-C67 fragment of amphidinol 3. Angewandte Chemie 118(43): 7416-7420.

Echigoya R, L Rhodes, Y Oshima \& M Satake. 2005. The structures of five new antifungal and hemolytic amphidinol analogs from Amphidinium carterae collected in New Zealand. Harmful Algae 4: 383-389.

Edwards M, DG Johns, SC Leterme, E Svendsen \& AJ Richardson. 2006. Regional climate change and harmful algal blooms in the northeast Atlantic. Limnology and Oceanography 51: 820-829.

Eschbach E, JP Scharsack, U John \& LK Medlin. 2001. Improved erythrocyte lysis assay in microtitre plates for sensitive detection and efficient measurement of haemolytic compounds from ichthyotoxic alga. Journal of Applied Toxicology 21:513-519.

Faust MA. 1992. Observations on the morphology and sexual reproduction of Coolia monotis (Dinophyceae). Journal of Phycology 28: 94-104.

Foden J, DA Purdie, S Morris \& S Nascimento. 2005. Epiphytic abundance and toxicity of Prorocentrum lima populations in the Fleet Lagoon, UK. Harmful Algae 4: 1063 1074.

Franklin DJ \& JA Berges. 2004. Mortality in cultures of the dinoflagellate Amphidinium carterae during culture senescence and darkness. Proceedings of the Royal Society of London B: Biological Sciences 271:2099-2107.

From N, K Richardson, EA Mousing \& PE Jensen. 2014. Removing the light history signal from normalized variable fluorescence $(\mathrm{Fv} / \mathrm{Fm})$ measurements on marine phytoplankton. Limnology and Oceanography 12: 776-783.

Gárate-Lizárraga I. 2012. Proliferation of Amphidinium carterae (Gymnodiniales: Gymnodiniaceae) in Bahia de La Paz, Gulf of California. CICIMAR Oceánides 27(2): 37-49.

GEOHAB. 2012. Global Ecology and Oceanography of Harmful Algal Blooms, GEOHAB Core Research Project: HABs in Benthic Systems. In: Berdalet E, P Tester \& AZingone (eds). 64 pp. IOC of UNESCO and SCOR, Paris and Newark. 
Gerath MW \& SW Chisholm. 1989. Change in photosynthetic capacity over the cell cycle in light dark synchronized Amphidinium carteri is due solely to the photocycle. Plant Physiology 91: 999-1005.

Gómez F, D Qiu, RM Lopes \& S Lin. 2015. Fukuyoa paulensis gen. et sp. nov., a new genus for the globular species of the dinoflagellate Gambierdiscus (Dinophyceae). PLoS ONE 10(4): 1-18.

Grasshoff K. 1976. Methods of seawater analysis, 317 pp. Verlag Chemie, New York.

Guillard RR \& JH Ryther. 1962. Studies on marine planktonic diatoms. I. Cyclotella nana Hustedt and Detonula confervacaea (Cleve) Gran. Canadian Journal of Microbiology 8: 229-239.

Hallegraeff GM. 2003. Harmful algal blooms: a global overview. In: Hallegraeff GM, DM Anderson \& AD Cembella (eds). Manual on harmful marine microalgae. Monographs on Oceanographic Methodology 11: 25-49. UNESCO, Paris.

Hallegraeff GM. 2010. Ocean climate change, phytoplankton community responses, and harmful algal blooms: A formidable predictive challenge. Journal of Phycology 46: 220-235.

Hinder SL, GC Hays, CJ Brooks, AP Davies, M Edwards, AW Walne \& MB Gravenor. 2011. Toxic marine microalgae and shellfish poisoning in the British isles: history, review of epidemiology, and future implications. Environmental Health 10: 54, <doi:10.1186/1476-069X-1054>

Holmes MJ, RJ Lewis, A Jones \& AW Hoy. 1995. Cooliatoxin, the first toxin from Coolia monotis (Dinophyceae). Natural Toxins 3: 355-362.

Hoppenrath M, SA Murray, N Chomérat \& T Horiguchi. 2014. Marine benthic dinoflagellates -unveiling their worldwide biodiversity, 276 pp. Kleine Senckenberg-Reihe, Stuttgart.

Ignatiades L \& O Gotsis-Skretas. 2010. A review on toxic and harmful algae in Greek coastal waters (E. Mediterranean Sea). Toxins 2: 1019-1037.

Ismael AA. 2014. First records of Coolia monotis Meunier along Alexandria coast-Egypt. Egyptian Journal of Aquatic Reseach 40: 19-25.

Ismael AAH \& Y Halim. 2012. Potentially harmful Ostreopsis spp. in the coastal waters of Alexandria-Egypt. Mediterranean Marine Science 13(2): 208-212.

Ismael AAH, Y Halim \& AG Khalil. 1999. Optimum growth conditions for Amphidinium carterae Hulburt from eutrophic waters in Alexandria (Egypt) and its toxicity to the brine shrimp Artemia salina. Grana 38: 179-185.

Jeong SY, K Ishida, Y Ito, S Okada \& M Murakami. 2003. Bacillamide, a novel algicide from the marine bacterium, Bacillus sp. SY-1, against the harmful dinoflagellate, Cochlodinium polykrikoides. Tetrahedron Letters 44: 80058007.
Kirkwood D. 1996. Nutrients: practical notes on their determination in sea water. ICES Techniques in Marine Environmental Sciences 17: 1-25. International Council for the Exploration of the Sea, Copenhagen.

Kobayashi J \& M Tsuda. 2004. Amphidinolides, bioactive macrolides from symbiotic marine dinoflagellates. Natural Product Reports 21: 77-93.

Kromkamp J \& J Peene. 1999. Estimation of phytoplankton photosynthesis and nutrient limitation in the Eastern Scheldt estuary using variable fluorescence. Aquatic Ecology 33: 101104.

Lakeman MB, P von Dassow \& RA Cattolico. 2009. The strain concept in phytoplankton ecology. Harmful Algae 8: 746-758.

Laza-Martínez A, E Orive \& I Miguel. 2011. Morphological and genetic characterization of benthic dinoflagellates of the genera Coolia, Ostreopsis and Prorocentrum from the south-eastern Bay of Biscay. European Journal of Phycology 46:45-65.

Lee JJ, M Shpigel, S Freeman, O Zmora, S Mcleod, S Bowen, M Pearson \& A Szostek. 2003. Physiological ecology and possible control strategy of a toxic marine dinoflagellate, Amphidinium sp., from the benthos of a mariculture pond. Aquaculture 217:351-371.

Liang JL, LJ Long, S Zhang \& J Wu. 2009. Cooliatin, an unprecedented natural dioxocyclononane from dinoflagellate Coolia monotis from South China Sea. Chemical \& Pharmaceutical Bulletin 57: 888-889.

Mandal SK, RP Singh \& V Patel. 2011. Isolation and characterization of exopolysaccharide secreted by a toxic dinoflagellate Amphidinium carterae Hulburt 1957 and its probable role in harmful algal blooms (HABs). Microbial Ecology 62: 518-527.

Meng YH, RM Van Wagoner, I Misner, C Tomas \& JLC Wright. 2010. Structure and biosynthesis of amphidinol 17, a hemolytic compound from Amphidinium carterae. Journal of Natural Products 73: 409-415.

Michel C, L Legendre, JC Therriault \& S Demers. 1989. Photosynthetic responses of Arctic sea-ice microalgae to shortterm temperature acclimation. Polar Biology 9: 437-442.

Momigliano P, L Sparrow, D Blair \& K Heimann. 2013. The diversity of Coolia spp. (Dinophyceae Ostreopsidaceae) in the central Great Barrier Reef region. PLoS ONE 8(10): e79278. <doi:10.1371/journal.pone.0079278>

Moore SK, VL Trainer, NJ Mantua, MS Parker, EA Laws, LC Backer \& LE Fleming. 2008. Impacts of climate variability and future climate change on harmful algal blooms and human health. Environmental Health 7: 1-12.

Morton SL, DR Norris \& JW Bomber. 1992. Effect of temperature, salinity and light intensity on the growth and seasonality of toxic dinoflagellates associated with ciguatera. Journal of Experimental Marine Biology and Ecology 157: 79-90. 
Nakajima I, Y Oshima \& T Yasumoto. 1981. Toxicity of benthic dinoflagellates in Okinawa. Bulletin of the Japanese Society of Scientific Fisheries 47: 1029-1033.

Nascimento SM. 2003. Phytoplankton blooms and water quality of the Fleet Lagoon, Dorset, UK, including studies of isolated toxic strains of Alexandrium minutum and Prorocentrum lima. PhD Thesis, University of Southampton, Southampton, Hampshire, 214 pp.

Nascimento SM, DA Purdie \& S Morris. 2005. Morphology, toxin composition and pigment content of Prorocentrum lima strains isolated from a coastal lagoon in southern UK. Toxicon 45: 633-649.

Nayak BB, I Karunasagar \& I Karunasagar. 1997. Influence of bacteria on growth and hemolysin production by the marine dinoflagellate Amphidinium carterae. Marine Biology 130: 35-39.

Neely T \& L Campbell. 2006. A modified assay to determine hemolytic toxin variability among Karenia clones isolated from the Gulf of Mexico. Harmful Algae 5: 592-598.

Okolodkov YB, G Campos-Bautista, I Gárate-Lizárraga, JAG González-González, M Hoppenrath \& V Arenas. 2007. Seasonal changes of benthic and epiphytic dinoflagellates in the Veracruz reef zone, Gulf of Mexico. Aquatic Microbial Ecology 47: 223-237.

Olson RJ \& SW Chisholm. 1986. Effects of light and nitrogen limitation on the cell cycle of the dinoflagellate Amphidinium carteri. Journal of Plankton Research 8(4): 785-793.

Penna A, M Vila, S Fraga, MG Giacobbe, F Andreoni, $\mathbf{P}$ Riobó \& C Vernesi. 2005. Characterization of Ostreopsis and Coolia (Dinophyceae) isolates in the western Mediterranean Sea based on morphology, toxicity and internal transcribed spacer 5.8s rDNA sequences. Journal of Phycology 41: 212-225.

Peperzak L. 2003. Climate change and harmful algal blooms in the North Sea. Acta Oecologica 24: S139-S144.

Raven J \& RJ Geider. 1988. Temperature and algal growth. New Phytologist 110: 441-461.

Rhodes LL \& AE Thomas. 1997. Coolia monotis (Dinophyceae): A toxic epiphytic microalgal species in New Zealand. New Zealand Journal of Marine and Freshwater Research 31: 139-141.

Rhodes L, J Adamson, T Suzuki, L Briggs \& I Garthwaite. 2000. Toxic marine epiphytic dinoflagellates, Ostreopsis siamensis and Coolia monotis (Dinophyceae), in New Zealand. New Zealand Journal of Marine and Freshwater Research 34: 371-383.
Rhodes LL, KF Smith, R Munday, AI Selwood, PS Mcnabb, PT Holland \& MY Bottein. 2010. Toxic dinoflagellates (Dinophyceae) from Rarotonga, Cook Islands. Toxicon 56: 751-758.

Ritter A, SM Dittami, S Goulitquer, JA Correa, C Boyen, P Potin \& T Tonon. 2014. Transcriptomic and metabolomic analysis of copper stress acclimation in Ectocarpus siliculosus highlights signaling and tolerance mechanisms in brown algae. BMC Plant Biology 14: 116.

Sakshaug C, K Andresen, S Myklestad \& Y Olsen. 1983. Nutrient status of phytoplankton communities in Norwegian waters (marine, brackish and fresh) as revealed by their chemical composition. Journal of Plankton Research 5(2): 175-196.

Senft C, DE Avery \& HG Dam. 2011. A novel approach to identifying PST tolerant copepods: An individual ingestion assay. Harmful Algae 10: 804-810.

Shears NT \& PM Ross. 2009. Bloom of benthic dinoflagellates of the genus Ostreopsis; and increasing and ecologically important phenomenon on temperate reef in New Zealand and worldwide. Harmful Algae 8: 916-925.

Strom SL \& TA Morello. 1998. Comparative growth rates and yields of ciliates and heterotrophic dinoflagellates. Journal of Plankton Research 20(3): 571-584.

Sugg LM \& FM Van Dolah. 1999. No evidence for an allelopathic role of okadaic acid among ciguatera-associated dinoflagellates. Journal of Phycology 35: 93-103.

Suggett, DJ., CM Moore, AE Hickman \& RJ Geider. 2009. Interpretation of fast repetition rate (FRR) fluorescence: signature of phytoplankton community structure versus physiological state. Marine Ecology Progress Series 376: 119.

Taylor FJR, Y Fukuyo, J Larsen \& GM Hallegraeff. 2003. Taxonomy of harmful dinoflagellates. In: Hallegraeff GM, DM Anderson \& AC Cembella (eds). Manual on harmful marine microalgae. Monographs on Oceanographic Methodology 11: 389-432. UNESCO, Paris.

Teegarden GJ \& AD Cembella. 1996. Grazing of toxic dinoflagellates, Alexandrium spp., by adult copepods of coastal Maine: Implications for the fate of paralytic shellfish toxins in marine food webs. Journal of Experimental Marine Biology and Ecology 196: 145-176.

Weber GJ, PE O'Sullivan \& P Brassley. 2006. Hindcasting of nutrient loadings from its catchment on a highly valuable coastal lagoon: the example of the Fleet, Dorset, UK, 18662004. Saline Systems 2: 15 <doi:10.1186/1746-1448-2-15> 